\title{
EFFECT OF ACCEL ON THE VASE LIFE AND POST HARVEST QUALITY OF ALSTROEMERIA (Alstroemeria aurantiaca L.) CUT FLOWERS
}

\author{
Mutui, T.M. ${ }^{1}$ V. E. Emongor ${ }^{2}$ and M. J. Hutchinson ${ }^{2}$ \\ ${ }^{1}$ Department of Horticulture, Moi University, P. O. Box 1125, Eldoret, Kenya. \\ ${ }^{2}$ Department of Crop Science, University of Nairobi, P. O. Box 29053, Nairobi, Kenya.
}

\begin{abstract}
Freshly cut flowering stems of Alstroemeria 'Yellow King' and 'Marina' were placed in glass jars containing solutions of Accel at 0, 25, 50, 75 and $100 \mathrm{mg} /$ litre BA equivalent and arranged in a completely randomised design with 3 replicates. The effect of Accel on the vase life and quality of Alstroemeria was investigated. Flowers held in Accel at 25 or $50 \mathrm{mg} /$ litre BA equivalent consistently increased the number of days to full opening of primary florets and delayed the onset of flower senescence as measured by days to $50 \%$ petal fall and days to $50 \%$ leaf yellowing. Accel at $25 \mathrm{mg} /$ litre BA equivalent significantly increased the leaf nitrogen and chlorophyll content of Alstroemeria cut flowers. High Accel concentrations of 50, 75 and $100 \mathrm{mg} /$ litre BA equivalent reduced significantly the leaf water content of Alstroemeria cut flowers. Accel at 75 and $100 \mathrm{mg} /$ litre BA equivalent increased leaf dry weight of Alstroemeria cut flowers. Our results indicate that Accel at $25 \mathrm{mg} /$ litre $B A$ equivalent has the potential to be used as a commercial cut flower preservative solution for delaying flower senescence, prolonging the vase life and enhancing post harvest quality of Alstroemeria cut flowers.
\end{abstract}

\section{INTRODUCTION}

The effects of cytokinins and gibberellins on leaf senescence vary greatly among plant species. In broccoli, pulsing cut stems with benzyladenine (BA) concentrations as low as $5 \mathrm{mg} /$ litre effectively prevented discolouration, while in others it was ineffective, even at much higher concentrations (Halevy and Wittwer, 1966). Cytokinins and gibberellins have been reported in several studies to improve the post harvest vase life of many cut flowers. Leaf yellowing of excised Easter lily leaves was significantly delayed by application of gibberellic acids $\left(\mathrm{GA}_{3}\right) \geq 250$ $\mathrm{mg} / \mathrm{litre}$ or benzyladenine $(\mathrm{BA}) \geq 50 \mathrm{mg} / \mathrm{litre}$ (Han, 1995). Halevy (1986) reported that gibberellic acid did not delay leaf senescence in most plant species and its content in tissues was not correlated with senescence.

Alstroemeria cut flowers are popular among small and large scale growers in Kenya because they grow easily both in the open fields and under shade netting and partly due to their simple management practices. The major problem associated with Alstroemeria is premature yellowing before senescence of the secondary florets. This study was therefore designed to investigate the effect of Accel $\left(\mathrm{BA}+\mathrm{GA}_{4+7}\right)$ on the vase life and the post harvest quality of Alstroemeria cut flowers.

\section{MATERIALSANDMETHODS}

Flowering stems of Alstroemeria cvs 'Yellow King' and 'Marina' were harvested just as the primary florets opened on $2^{\text {nd }}$ April and $23^{\text {rd }}$ May 1997. The mother plants were 24 months old, and they were grown in the open, on a commercial farm in South Kinangop, Kenya (2,558 m). Shoots between $70 \mathrm{~cm}$ and $90 \mathrm{~cm}$ long were pulled from the rhizomes in the morning, sorted, graded to $62 \mathrm{~cm}$, packed and received the same day in our laboratory at the Department of Crop Science, University of Nairobi.

The flowers were immediately unpacked, the lower $10 \mathrm{~cm}$ of the stems were defoliated and $2 \mathrm{~cm}$ were cut off under water to avoid air embolism. Eight stems were used for each treatment. The stems of the flowers were placed in glass jars that contained Accel at $0,25,50,75$ or $100 \mathrm{mg} /$ litre BA equivalent. Accel is a liquid concentrate containing 20 $\mathrm{g}$ a.i / litre BA and $2.0 \mathrm{~g}$ a.i / litre $\mathrm{GA}_{4+7}$ (Abbott Laboratories, North Chicago, Illinois, USA). The glass jars containing Accel at various concentrations were arranged in a completely randomised design (CRD) with 3 replicates. Experiments were carried out in a laboratory at an air temperature of $23^{\circ} \mathrm{C} \pm 2{ }^{\circ} \mathrm{C}$ and at $74-81 \% \mathrm{RH}$ and continuous lighting with cool-white Sylvania fluorescent lamps $(65 \mathrm{~W}, 240 \mathrm{~V})$ at an intensity of $4160 \mathrm{~J} / \mathrm{S}$. 
The vase life of Alstroemeria cut flowers was determined by counting the number of days from harvest to full opening of the primary florets, days from harvest to $50 \%$ petal fall and $50 \%$ leaf yellowing from daily observations. Chlorophyll content was determined from 5 leaves per replicate. Two discs per leaf ( $9 \mathrm{~mm}$ diameter) were cut using a cork borer. The ten discs were extracted in $4 \mathrm{ml}$ of $0.1 \mathrm{~N} \mathrm{HCl}$ in methanol at $21^{\circ} \mathrm{C}$ in a dark room for 24 hours. Absorbance of extracts were measured using a WPA S105 spectrophotometer according to Douglas (1983). The leaf chlorophyll content was determined as absorbance of these extracts at $653 \mathrm{~nm}$ (Douglas, 1983). The following equation was used to calculate the relative total chlorophyll content (Douglas, 1983).

Chlorophyll $\left(\mathrm{mg} / \mathrm{cm}^{2}\right)$ of Alstroemeria $=24.88 \times \mathrm{A}_{653}$

Dry weight of the leaves was determined from eight grams of fresh leaves, which were weighed immediately after their removal from the shoots using Sartorius digital balance ELE. The leaf samples were put in brown paper bags and oven dried at $66^{\circ} \mathrm{C}$ to constant weight (72 hours) using Memmert, UL80 780218 incubator, then reweighed for dry weight.

Water content of the leaves was determined by subtracting dry weights from their corresponding fresh weights $(8$ grams).
Total nitrogen content (\%) was analyzed using Microkjeldahl method according to the Association of Official Analytical Chemists (A.0.A.C, 1986).

Analysis of variance was performed on the data collected using the general linear models (Proc GLM) procedure of the Statistical Analysis System (SAS, 1990) program package. Proc Univariate procedure was carried out on residuals to support the assumptions of normality made by the researchers.

\section{RESULTS}

\section{Vase life of Alstroemeria cut flowers}

Accel at 25,50 or $75 \mathrm{mg} /$ litre BA equivalent increased the mean number of days to full opening of the primary florets (Table 1). However, Accel at $100 \mathrm{mg} /$ litre had no effect in the opening of the primary florets. As the concentration of Accel increased, there was a decrease in the days to full opening of primary florets. There were no significant differences between Accel at 50, 75 and $100 \mathrm{mg} / \mathrm{litre}$ BA equivalent in response to days to full opening of the primary florets. Accel at $50 \mathrm{mg} /$ litre BA equivalent was different from 75 and $100 \mathrm{mg} /$ litre in the first experiment and was different from $100 \mathrm{mg} / \mathrm{litre}$ in the second experiment. The cultivar difference was significant, since 'Yellow King' took longer time to open than 'Marina', in both experiments .

Table 1. Effect of Accel on the vase life of Alstroemeria cut flowers

\begin{tabular}{llll|lll}
\hline & \multicolumn{3}{c|}{ First Experiment } & \multicolumn{3}{c}{ Second Experiment } \\
\hline $\begin{array}{l}\text { Accel (BA } \\
\text { equivalent } \\
\mathrm{mg} / \text { litre) }\end{array}$ & $\begin{array}{l}\text { Days to opening } \\
\text { of primary florets }\end{array}$ & $\begin{array}{l}\text { Days to 50\% } \\
\text { petal fall }\end{array}$ & $\begin{array}{l}\text { Days to 50\% } \\
\text { leaf yellowing }\end{array}$ & $\begin{array}{l}\text { Days to opening } \\
\text { of primary florets }\end{array}$ & $\begin{array}{l}\text { Days to 50\% } \\
\text { petal fall }\end{array}$ & $\begin{array}{l}\text { Days to 50\% leaf } \\
\text { yellowing }\end{array}$ \\
\hline 0 (control) & 4.5 & 14.17 & 18.5 & 4.17 & 14.33 & 14.5 \\
25 & 6 & 19.5 & 20.33 & 5.5 & 16.17 & 20.5 \\
50 & 5.5 & 18.5 & 21 & 5 & 15.5 & 18.83 \\
75 & 5.33 & 17.33 & 18.67 & 5 & 15.33 & 17.5 \\
100 & 5 & 15.5 & 17 & 4.67 & 14.67 & 16.83 \\
Significance & $\mathrm{L}^{* * *} \mathrm{Q}^{* *} \mathrm{C}^{* *}$ & $\mathrm{~L}^{* * *} \mathrm{Q}^{* * * *} \mathrm{C}^{* * *}$ & $\mathrm{~L}^{* * *} \mathrm{Q}^{* *}$ & $\mathrm{~L}^{* *} \mathrm{Q}^{*}$ & $\mathrm{~L}^{* *} \mathrm{Q}^{* *} \mathrm{C}^{*}$ & $\mathrm{~L}^{* * *} \mathrm{Q}^{* * *} \mathrm{C}^{* * *}$ \\
Cultivars & & & & & & \\
Yellow King & $6.00 \mathrm{a}$ & $18.13 \mathrm{a}$ & $18.73 \mathrm{~b}$ & $5.13 \mathrm{a}$ & $15.33 \mathrm{a}$ & $17.07 \mathrm{~b}$ \\
Marina & $4.53 \mathrm{~b}$ & $15.87 \mathrm{~b}$ & $19.47 \mathrm{a}$ & $4.60 \mathrm{~b}$ & $15.07 \mathrm{a}$ & $18.20 \mathrm{a}$ \\
Significance & $* * * *$ & $* * * *$ & $*$ & $*$ & $\mathrm{~ns}$ & $* * *$ \\
LSD & 0.39 & 0.76 & 0.55 & 0.49 & 0.45 & 0.61 \\
\hline
\end{tabular}

${ }^{\mathrm{z}} \mathrm{T}$ he response was linear $(\mathrm{L})$, quadratic $(\mathrm{Q})$ or cubic $(\mathrm{C})$.

$*, * *, * * *, * * * *, \mathrm{~ns}$, significant within columns at $\mathrm{P}=0.05,0.01,0.001,0.0001$ or non significant, respectively. 
Holding Alstroemeria in Accel delayed flower senescence by increasing the number of days to $50 \%$ petal fall, in the first experiment (Table 1). Accel at $25 \mathrm{mg} /$ litre BA equivalent increased the vase life of petals by 5.33 days compared to the control. There was no significant difference between 25 and $50 \mathrm{mg} /$ litre BA equivalent. However, 75 and $100 \mathrm{mg} /$ litre BA equivalent promoted flower senescence in comparison to $25 \mathrm{mg} /$ litre BA equivalent. In the second experiment, Accel at 25,50 or $75 \mathrm{mg} /$ litre increased the days to $50 \%$ petal fall. However, Accel at $100 \mathrm{mg} /$ litre had no effect on days to $50 \%$ petal fall (Table 1). The two cultivars responded differently to Accel treatment. 'Yellow King' took a longer time for petals to fall than 'Marina' in the first experiment while in the second experiment, the same trend was observed though the cultivar response was non significant (Table 1).

In the first experiment, Accel at 25 or $50 \mathrm{mg} / \mathrm{litre} \mathrm{BA}$ equivalent delayed cut flower senescence by extending the number of days to the onset of $50 \%$ leaf yellowing. Accel at $75 \mathrm{mg} /$ litre BA equivalent had no effect on the onset of $50 \%$ leaf yellowing. Accel at $100 \mathrm{mg} / \mathrm{litre}$ BA equivalent promoted the onset of $50 \%$ leaf yellowing (Table 1). In the second experiment, all the levels of Accel delayed the onset of $50 \%$ leaf yellowing. However, higher levels 50,75 or $100 \mathrm{mg} /$ litre BA equivalent were less effective compared to $25 \mathrm{mg} /$ litre BA equivalent. 'Marina' took a longer time to attain $50 \%$ leaf yellowing than 'Yellow King'.

\section{Leaf chlorophyll content of Alstroemeria cut flowers}

Accel consistently retarded the degradation of the leaf chlorophyll content, in both experiments (Table 2). Holding Alstroemeria cut flowers in Accel solutions above $50 \mathrm{mg} /$ litre BA equivalent resulted in a non significant decrease in the leaf chlorophyll content, in the first experiment. In the second experiment, Accel at $25 \mathrm{mg}$ /litre BA equivalent was the most effective in retarding chlorophyll degradation as evidenced by the high leaf chlorophyll content retention. At 14 days after harvest, in the second experiment 50, 75 and $100 \mathrm{mg} /$ litre BA equivalent significantly reduced leaf chlorophyll content compared to $25 \mathrm{mg}$ /litre BA equivalent. Generally the cultivars were not different from each other, except in the first experiment, 21 days after harvest when 'Marina' retained higher chlorophyll in the leaves than 'Yellow King'.

\section{Dry weight of the leaves}

Accel at 75 or $100 \mathrm{mg} /$ litre BA equivalent significantly increased the leaf dry weight of Alstroemeria, in both experiments (Table 3). In the first experiment, 75 and 100 $\mathrm{mg} /$ litre BA equivalent were significantly different. However, the difference was not apparent in the second experiment, except 14 days after harvest (Table 3). In both experiments, 25 or $50 \mathrm{mg} /$ litre Accel had no effect on leaf dry matter retention, except during the second experiment,

Table 2. Effect of Accel on the chlorophyll content of the leaves $\left(\mathrm{mg} / \mathrm{cm}^{2}\right)$ of Alstroemeria cut flowers

\begin{tabular}{|c|c|c|c|c|c|c|}
\hline \multirow{3}{*}{$\begin{array}{l} \\
\text { Accel(BA } \\
\text { equivalent } \\
\text { mg/litre) } \\
\end{array}$} & \multicolumn{3}{|c|}{ First Experiment } & \multicolumn{3}{|c|}{ Second Experiment } \\
\hline & \multicolumn{3}{|c|}{ Chlorophyll content of leaves $\left(\mathrm{mg} / \mathrm{cm}^{2}\right)$} & \multicolumn{3}{|c|}{ Chlorophyll content of leaves $\left(\mathrm{mg} / \mathrm{cm}^{2}\right)$} \\
\hline & 7 days & 14 days & 21 days & 7 days & 14 days & 21 days \\
\hline 0 (control) & 1.52 & 1.34 & 0.81 & 0.74 & 0.55 & 0.38 \\
\hline 25 & 2.1 & 1.94 & 1.75 & 2.28 & 2.16 & 1.68 \\
\hline 50 & 2.34 & 2.3 & 1.93 & 1.98 & 1.77 & 1.41 \\
\hline 75 & 2.17 & 2.1 & 1.65 & 1.87 & 1.43 & 1.32 \\
\hline 100 & 1.94 & 1.84 & 1.36 & 1.59 & 1.34 & 1.2 \\
\hline Significance $^{\mathrm{z}}$ & $\mathrm{L}^{* *}$ & $\mathrm{~L}^{* *}$ & $\mathrm{~L}^{* * *} \mathrm{Q}^{* *}$ & $\mathrm{~L}^{* * * *} \mathrm{Q}^{* * *} \mathrm{C}^{* *}$ & $\mathrm{~L}^{* * * *} \mathrm{Q}^{* * *}$ & $\mathrm{~L}^{* * * *} \mathrm{Q}^{* * * *} \mathrm{C}^{* * * *}$ \\
\hline Cultivars & & & & & & \\
\hline Yellow King & $1.94 \mathrm{a}$ & $1.80 \mathrm{a}$ & $1.22 b$ & $1.81 \mathrm{a}$ & $1.50 \mathrm{a}$ & $1.21 \mathrm{a}$ \\
\hline Marina & $2.08 \mathrm{a}$ & $2.01 \mathrm{a}$ & $1.78 \mathrm{a}$ & $1.57 \mathrm{a}$ & $1.40 \mathrm{a}$ & $1.18 \mathrm{a}$ \\
\hline Significance & $\mathrm{ns}$ & $\mathrm{ns}$ & $* * *$ & ns & ns & ns \\
\hline LSD & 0.2 & 0.22 & 0.26 & 0.27 & 0.23 & 0.11 \\
\hline
\end{tabular}

${ }^{\mathrm{z}}$ The response was linear $(\mathrm{L})$, quadratic $(\mathrm{Q})$ or cubic $(\mathrm{C})$.

$*, * *, * * *, * * * *, \mathrm{~ns}$, significant within columns at $\mathrm{P}=0.05,0.01,0.001,0.0001$ or non significant, respectively. 
14 days after harvest, when there was a significant dry matter retention. There was no significant cultivar difference, 7 days after harvest, however, 'Marina' retained higher dry weight than 'Yellow King' 21 days after harvest, in experiment one. During the second experiment, 'Yellow King' maintained higher dry weight than 'Marina' at similar Accel levels.

\section{Water content of the leaves}

The higher Accel levels 75 or $100 \mathrm{mg} /$ litre BA equivalent significantly decreased the leaf water content, in both experiments (Table 4). Accel at 25 and $50 \mathrm{mg} /$ litre BA equivalent were not different from the control, in the first experiment. However, in the second experiment, 14 and 21 days after harvest, $50 \mathrm{mg} /$ litre BA equivalent significantly

Table 3. Effect of Accel on dry weight of the leaves of Alstroemeria cut flowers

\begin{tabular}{lll|lll}
\hline \multicolumn{3}{c|}{ First Experiment } & \multicolumn{3}{c}{ Second Experiment } \\
\hline $\begin{array}{l}\text { Accel (BA } \\
\text { equivalent }\end{array}$ & \multicolumn{2}{l}{ Dry weight $(\mathrm{g})$ of leaves } & \multicolumn{3}{|l}{ Dry weight $(\mathrm{g})$ of the leaves } \\
\cline { 2 - 6 } & 7 days & 21 days & 7 days & 14 days & 21 days \\
\hline 0 (control) & 1.26 & 1.31 & 1.1 & 3.28 & 3.87 \\
25 & 1.17 & 1.23 & 1.42 & 3.95 & 4.91 \\
50 & 1.34 & 1.42 & 1.5 & 4.1 & 5.7 \\
75 & 1.53 & 1.6 & 1.81 & 4.55 & 7.1 \\
100 & 1.71 & 2.01 & 2.18 & 5.83 & 7.5 \\
Significance & $\mathrm{L}^{*} \mathrm{Q}^{* *} \mathrm{C}^{*}$ & $* * * *$ & $* * *$ & $\mathrm{~L}^{* *} \mathrm{Q}^{*} \mathrm{C}^{* *} * * * *$ \\
Cultivars & & & & & \\
Yellow King & $1.41 \mathrm{a}$ & $1.44 \mathrm{~b}$ & $1.94 \mathrm{a}$ & $5.84 \mathrm{a}$ & $6.89 \mathrm{a}$ \\
Marina & $1.39 \mathrm{a}$ & $1.59 \mathrm{a}$ & $1.26 \mathrm{~b}$ & $2.84 \mathrm{~b}$ & $4.74 \mathrm{~b}$ \\
Significance & $\mathrm{ns}$ & $*$ & $* * * *$ & $* * *$ & $* * * *$ \\
LSD & 0.07 & 0.12 & 0.28 & 0.3 & 0.85 \\
\hline
\end{tabular}

${ }^{\mathrm{z}}$ The response was linear $(\mathrm{L})$, quadratic $(\mathrm{Q})$ or cubic $(\mathrm{C})$.

$*, * *, * * *, * * * *, \mathrm{~ns}$, significant within columns at $\mathrm{P}=0.05,0.01,0.001,0.0001$

Table 4. Effect of Accel on water content of the leaves of Alstroemeria cut flowers

\begin{tabular}{|c|c|c|c|c|c|}
\hline \multicolumn{3}{|c|}{ First Experiment } & \multicolumn{3}{|c|}{ Second Experiment } \\
\hline \multirow{2}{*}{$\begin{array}{l}\text { Accel (BA } \\
\text { equivalent } \mathrm{mg} / \text { litre) }\end{array}$} & \multicolumn{2}{|c|}{ Moisture content (g) of leaves } & \multicolumn{3}{|c|}{ Moisture content (g) of leaves } \\
\hline & 7 days & 21 days & 7 days & 14 days & 21 days \\
\hline 0 (control) & 6.75 & 6.69 & 6.9 & 4.72 & 4.13 \\
\hline 25 & 6.83 & 6.77 & 6.58 & 4.05 & 3.09 \\
\hline 50 & 6.66 & 6.58 & 6.5 & 3.9 & 2.3 \\
\hline 75 & 6.47 & 6.4 & 6.2 & 3.45 & 0.91 \\
\hline 100 & 6.29 & 5.99 & 5.82 & 2.17 & 0.5 \\
\hline Significance ${ }^{\mathrm{z}}$ & $\mathrm{L}^{*} \mathrm{Q}^{\pi *} \mathrm{C}^{*}$ & $* * * *$ & $* * *$ & $\mathrm{~L}^{* \pi} \mathrm{Q}^{*} \mathrm{C}^{\text {** }}$ & $* * * *$ \\
\hline \multicolumn{6}{|l|}{ Cultivars } \\
\hline Yellow King & $6.59 \mathrm{a}$ & $6.56 a$ & $6.06 \mathrm{~b}$ & $2.16 \mathrm{~b}$ & $1.11 \mathrm{~b}$ \\
\hline Marina & $6.61 \mathrm{a}$ & $6.41 \mathrm{~b}$ & $6.74 \mathrm{a}$ & $5.16 \mathrm{a}$ & $3.26 \mathrm{a}$ \\
\hline Significance & ns & $*$ & $* * * *$ & $* * * *$ & $* * * *$ \\
\hline LSD & 0.07 & 0.12 & 0.28 & 0.3 & 0.85 \\
\hline
\end{tabular}

\footnotetext{
${ }^{\mathrm{z}}$ The response was linear (L), quadratic (Q) or cubic (C).

$*, * *, * * *, * * * *, \mathrm{~ns}, \mathrm{significant}$ within columns at $\mathrm{P}=0.05,0.01,0.001,0.0001$ or non significant, respectively.
} 
reduced the leaf water content of Alstroemeria. At 7 days after harvest, in the second experiment $50 \mathrm{mg} /$ litre BA equivalent had no effect on leaf water content. 'Marina ' maintained higher water content in the leaves than 'Yellow King' throughout the second experiment. The reverse was true, 21 days after harvest, in the first experiment.

\section{Leaf total nitrogen content}

Increasing the concentration of Accel resulted in decreased rate of nitrogen degradation, as evidenced by high retention of nitrogen in the leaves, in both experiments (Table 5). Higher Accel levels 50, 75 or $100 \mathrm{mg} /$ litre BA equivalent were most effective in retarding chlorophyll degradation. In the first experiment, there were no differences between 50,75 or $100 \mathrm{mg} / \mathrm{litre} \mathrm{BA}$ equivalent in retarding chlorophyll degradation. The same was true for 75 or $100 \mathrm{mg} /$ litre BA equivalent, in the second experiment. 'Marina' retained higher leaf nitrogen content than 'Yellow King', although it was not significant at 21 days after harvest, in both experiments, respectively.

Table 5. Effect of Accel on total nitrogen content (\%) of the leaves of Alstroemeria cut flowers.

\begin{tabular}{|c|c|c|c|c|c|}
\hline \multicolumn{3}{|c|}{ First Experiment } & \multicolumn{3}{|c|}{ Second Experiment } \\
\hline \multirow{2}{*}{$\begin{array}{l}\text { Accel (BA } \\
\text { equivalent } \mathrm{mg} / \text { litre) }\end{array}$} & \multicolumn{2}{|c|}{ Dry weight (g) of leaves } & \multicolumn{3}{|c|}{ Dry weight (g) of the leaves } \\
\hline & 7 days & 21 days & 7 days & 14 days & 21days \\
\hline 0 (control) & 2.93 & 2.26 & 1.91 & 1.70 & 1.60 \\
\hline 25 & 3.36 & 2.77 & 3.07 & 2.71 & 2.66 \\
\hline 50 & 3.39 & 3.19 & 3.24 & 2.96 & 2.77 \\
\hline 75 & 3.47 & 3.22 & 3.30 & 3.07 & 2.87 \\
\hline 100 & 3.53 & 3.24 & 3.35 & 3.15 & 3.01 \\
\hline Significance $^{\mathrm{z}}$ & $\mathrm{L}^{* * *} \mathrm{Q}^{* *} \mathrm{C}^{*}$ & $\mathrm{~L}^{* *}$ & $\mathrm{~L}^{* * *} \mathrm{Q}^{*} \mathrm{C}^{* *}$ & $\mathrm{~L}^{* * * * *} \mathrm{Q}^{* * * * *} \mathrm{C}^{* * * * *}$ & $\mathrm{~L}^{* * * * *} \mathrm{Q}^{* * * * *} \mathrm{C}^{* * * * *}$ \\
\hline \multicolumn{6}{|l|}{ Cultivars } \\
\hline Yellow King & $3.15 b$ & $2.89 a$ & $2.77 b$ & $2.66 b$ & $2.56 \mathrm{a}$ \\
\hline Marina & $3.52 \mathrm{a}$ & $2.98 \mathrm{a}$ & $3.17 \mathrm{a}$ & $2.77 \mathrm{a}$ & $2.60 \mathrm{a}$ \\
\hline Significance & $* * * *$ & ns & $* * * *$ & $* * * *$ & ns \\
\hline LSD & 0.1 & 0.16 & 0.11 & 0.05 & 0.09 \\
\hline
\end{tabular}

${ }^{\mathrm{Z}}$ The response was linear $(\mathrm{L})$, quadratic $(\mathrm{Q})$ or cubic $(\mathrm{C})$.

$*, * *, * * *, * * * *, \mathrm{~ns}$, significant within columns at $\mathrm{P}=0.05,0.01,0.001,0.0001$ or non significant, respectively.

\section{DISCUSSION}

Accel contains plant growth regulators namely benzyladenine (BA), a synthetic cytokinin and gibberellins $\left(\mathrm{GA}_{4+7}\right)$. Accel at 25,50 or $75 \mathrm{mg} / \mathrm{litre} \mathrm{BA}$ equivalent delayed the opening of primary florets of Alstroemeria cut flowers. Accel may have delayed primary floret opening because cytokinins and gibberellins are documented to delaying senescence of cut flowers (Salisbury and Ross, 1986). Results with external applications of cytokinins which delay senescence of various flowers support the possibility that the diminishing of internal concentrations of phytohormones (cytokinins and gibberellins) may be associated with senescence processes in cut flowers (Mayak and Halevy, 1970; Mayak and Dilley, 1976). Halevy and Kofranek (1976) reported that cytokinins were better inhibitors of flower abscission in roses. Accel at 25 or 50 $\mathrm{mg} /$ litre BA equivalent increased the vase life of Alstroemeria cut flowers. This could be explained by the role of BA (cytokinin) in ethylene biogenesis. Cytokinins have been shown to promote the synthesis of ACC synthase, an enzyme that catalyses the conversion of sulphur - adenosyl methionine to 1-aminocyclopropane1-carboxylic acid the immediate precursor of ethylene 
biogenesis (Yang, 1987). Hence BA may have promoted flower senescence indirectly through enhanced ethylene production.

In the present study, Accel at 25 or $50 \mathrm{mg} /$ litre BA equivalent delayed leaf yellowing, probably because BA and $\mathrm{GA}_{4+7}$ present in Accel, delayed protein degradation used in the synthesis of chlorophyll as evidenced by the significant retention of leaf nitrogen in Accel treated Alstroemeria cut flowers. Premature leaf yellowing of cut flowers has been associated to hormonal imbalance after harvest (Hofman, 1988). Cytokinins have been known to prevent leaf senescence by arresting degradation of protein and chlorophyll (Sacher, 1973). Gibberellins treatment to excised Easter lily leaves resulted in high chlorophyll retention (Han, 1995). Therefore, Accel could have delayed the degradation of chlorophyll by possibly delaying the breakdown of protein used in the synthesis of chlorophyll.

The dry weight increase induced by higher Accel levels was a BA response and not due to gibberellins, since treatment with 2.5 upto $10.0 \mathrm{mg} /$ litre $\mathrm{GA}_{4+7}$ significantly reduced the dry weight (data not shown). Gibberellins are known to promote fresh weight but not dry weights (Salisbury and Ross, 1986). The high retention in dry matter caused by Accel treatment may be attributed to cytokinins (BA) ability to promote carbohydrate metabolism and create new source - sink relationship (Dyer et al., 1990).

Accel at 75 or $100 \mathrm{mg} /$ litre BA equivalent decreased leaf water content, while $\mathrm{GA}_{4+7}$ increased the leaf water content (data not shown). This suggests that the increase in leaf water content at lower levels of Accel is attributed to $\mathrm{GA}_{4+7}$. Higher levels of BA in Accel, possibly increased water deficit by inducing stomatal opening, hence increasing the rate of water loss, which probably explains the observed decrease in leaf water content. Arad et al. (1973) reported similar results in barley. Gibberellins sometimes promote cell growth because they increase hydrolysis of starch, fructans and sucrose into glucose and fructose molecules which make the cell's water potential momentarily more negative. As a result of the decrease in water potential, water enters more rapidly, causing cell expansion but diluting the sugars (Salisbury and Ross, 1986).

In this study, Accel at all concentrations decreased the rate of leaf nitrogen degradation of Alstroemeria cut flowers during the study period compared to the control. Cytokinins have been reported to delay senescence by retarding the rate of breakdown of proteins rather than enhancing the rate of protein synthesis (Sacher, 1973). Richmond and Lang (1957) reported that kinetin (cytokinin) prevented accelerated protein loss that was typical to detached leaves. Salunke et al. (1962) explained that the primary step in the degradation of the soluble type ribonucleic acid is thought to involve the loss of the end adenine. A treatment with Accel, especially BA (cytokinin) may provide the necessary adenine and restore the soluble ribonucleic acid molecule. Thus protein breakdown could have been retarded in this study and the treated Alstroemeria cut flowers stayed fresh for a longer time. This was evidenced by high retention of nitrogen in the Alstroemeria leaves following Accel treatment. Fosket (1977) showed that cytokinins promoted cell division by increasing the transition of the cells from $\mathrm{G}_{2}$ to mitosis, thus increasing the rate of protein synthesis.

\section{CONCLUSION}

The results of our study indicate that Accel at 25 or $50 \mathrm{mg} /$ litre BA equivalent increased the vase life of Alstroemeria cut flowers as measured by number of days to full opening of primary florets, days to $50 \%$ petal fall and delayed the onset of $50 \%$ leaf yellowing. Accel also improved Alstroemeria cut flower quality by increasing the leaf dry matter and nitrogen content hence delaying the onset of leaf senescence. Therefore, Accel at $25 \mathrm{mg} /$ litre BA equivalent has the potential to be used as a commercial cut flower preservative for prolonging the vase life and post harvest quality of Alstroemeria cut flowers.

\section{ACKNOWLEDGEMENTS}

The authors are grateful to the German Academic Exchange Service (DAAD) for the financial support.

\section{REFERENCES}

A.O.A.C. 1984. Official methods of analysis of the Association of Analytical Chemists. $14^{\text {th }}$ edition. A.O.A.C., U.S.A.

Arad, S., Mizrahi, Y. and Richmond, A.E. 1973. Leaf water content and hormone effects on ribonuclease activity. Plant Physiology 52, 510-512.

Douglas, J.B. 1983. An evaluation of harvest indices for 'McIntosh' apples in two orchards. Hort Science 18, 216-218.

Dyer, D., Cotterman, J.C., Cotterman, C.D., Kerr, P.S. and Carlson, D.R. 1990. Cytokinins as metabolic stimulants which induce pod set. In: Pharis, R.P. and Rood. S.B. (eds.). 1988. Plant growth substances. 
Springer-Verlag, The Netherlands. pp. 457-467.

Fosket, D.E. 1977. The regulation of the plant cell cycle by cytokinin. In: Rost, T.L. and Gifford, E.M. Jr. (eds.). Mechanisms and control of cell division. Dowden, Hutchinson and Ross Inc., Stroudsburg, Pennsylvania. pp. 62-91.

Halevy, A.H. 1986. Whole plant senescence. In: Leshem, Y.Y. et al. (eds.). Developments in Crop Science. Elsevier, Amsterdam. pp. 119-125.

Halevy, A.H. and Kofranek, A.M. 1976. The prevention of flower bud and leaf abscission in pot roses during simulated transport. J. Amer. Soc. Hort. Sci. 101, 658660.

Halevy, A.H. and Wittwer, S.H. 1966. Effect of growth retardants on longevity of vegetables, mushrooms and cut flowers. Proceeding of the American Society for Horticultural Science 88, 582-590.

Han, S.S. 1995. Growth regulators delay foliar chlorosis of Easter lily leaves. J. Amer. Soc.Hort.Sci.120, 254-258.

Hofman, N.C. 1988. The importance of pre shipment treatment. International Floriculture Seminar Amsterdam. Pathfast Publ., Essex, England. pp. 109115.

Mayak, S. and Dilley, D.R. 1976. Regulation of senescence in carnations (Dianthus caryophyllus). Effect of abscisic acid and carbon dioxide on ethylene production. Plant Physiol.58, 663-665.

Mayak, S. and Halevy, A.H. 1970. Cytokinin activity in rose petals and its relation to senescence. Plant Physiol.46, 497-499.

Richmond, A.E. and Lang, A. 1957. Effect of kinetin on protein content and survival of detached Xanthium leaves.Science 125, 650-651.

Sacher, J.A. 1973. Senescence and post harvest physiology. Annual Review of Plant Physiology 24, 197-310.

Salisbury, F.B. and Ross, C.W. 1986. Plant physiology. Wadworth, California. pp. 319-329.

Salunke, D.K., Cooper, G.M., Dhaliwal, A.S., Boe, A.A. and Rivers, A.L. 1962. On storage of fruits: Effects of pre and post harvest treatments. Food Technology 16,
119.

SAS. 1990. SAS/STAT user's guide. $4^{\text {th }}$ edition. SAS Institute, Cary, North Carolina.

Yang, S.F. 1987. Regulation of biosynthesis and action of ethylene. Acta Horticulturae 201, 3-59. 